\section{Hva er psykososialt arbeid?}

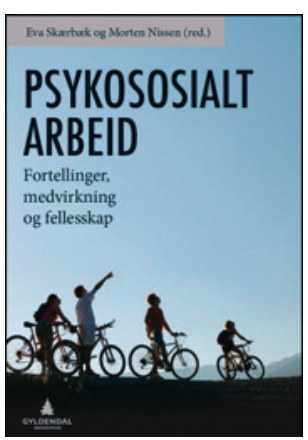

Eva Skærbæk, Morten Nissen, red.

Psykososialt arbeid

Fortellinger, medvirkning og felleskap.

189 s. Oslo: Gyldendal Akademisk, 2014.

Pris NOK 349

ISBN 978-82-05-46443-8

Alle forfatterne, unntatt én, er engasjert i et masterprogram i psykososialt arbeid ved Høgskolen i Østfold. Etter et blytungt teorikapittel illustrerer de på en interessant og leseverdig måte ulike praktiske tilnærminger av såkalt psykososialt arbeid. Barn, ungdom, rusmisbrukere og demente personer står sentralt i disse kapitlene. Den narrative og den salutogene tilnærmingen til pasienter eksemplifiseres fint. Forfatterne går også gjennom problematikken ved standardisering av tilnærmingsmetoder på en god måte.

Et hovedbudskap er at i psykososialt arbeid må behandlerne se hver enkelt pasient i relasjon til livsløp og sosial situasjon og ikke la diagnostikk redusere den hjelpetrengende til et objekt. Metoden for å hjelpe er å skape et pasient-hjelper-forhold som preges av «medvirkning» - i motsetning til å definere den hjelpetrengende som «bruker», for brukerbetegnelsen øker avstanden til den profesjonelle.

Boken har åpenbart en profesjonsbyggende hensikt. I den grad psykososialt arbeid er (blir) en egen spesialitet, vil det være legitimt med egen utdanning, egne tidsskrifter, egne konferanser og egne stillinger ved høgskolene. Midlene til dette må da tas fra utdanningen i de tradisjonelle hjelpeyrkene. Forfatterne argumenterer for at psykososialt arbeid er en såkalt «transdisiplin» som skal hente sin teori og sitt handlingspotensial fra biter av mange ulike disipliner, som medisin, psykologi, sosiologi, sosialantropologi osv. Det er særlig medisinen man distanserer seg fra, og noen forfattere karikerer den som uinteressert for psykososiale forhold hos sine pasienter. I virkeligheten inneholder utdanningen i psykiatri og klinisk psykologi, som jo er basert på den «bio-psyko-sosiale» modell, nøyaktig de samme elementene som forfatterne mener karakteriserer psykososialt arbeid alene.

Nettopp derfor vil kolleger innen allmennmedisin, samfunnsmedisin, barnepsykiatri og psykiatri ha glede av de praktiske eksemplene og de praksisnære refleksjonene som denne boken inneholder.

\section{Per Vaglum}

Professor emeritus, Avdeling for medisinsk atferdsvitenskap Universitetet i Oslo

\section{Kort og grei arbeidsbok om vold}

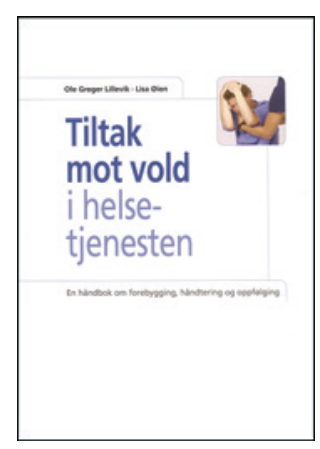

Ole Greger Lillevik, Lisa Øien Tiltak mot vold i helsetjenesten En håndbok om forebygging, håndtering og oppfølging. 93 s, tab, ill. Oslo: MEDLEX Norsk Helseinformasjon, 2013.

Pris NOK 198

ISBN 978-82-7841-782-9

Trusler og vold fra pasienter eller brukere mot helsepersonell får stadig mer oppmerksomhet, og denne boken er et bidrag til å sette temaet på dagsorden. Forfatterne er sykepleiere og høgskolelektorer, begge med forskningserfaring i forebygging av vold. Målgruppen er ansatte i helse- og omsorgstjenesten.

Hver av de fire hoveddelene avsluttes med arbeidsoppgaver, som ifølge forfatterne kan brukes på personalmøter eller på fagdager om trusler og vold på arbeidsplassen. Del 1 omhandler vold og aggresjon som fenomen. I del 2 følger forfatterne opp med råd om forebygging. De henviser til lovverk, leders ansvar og hva en tiltaksplan mot vold bør inneholde. I den tredje delen beskriver forfatterne ulike faser av aggresjon og aggresjonsdempende kommunikasjon. Prinsipper for beskyttelse og frigjøring presenteres gjennom tekst og et stort antall bilder. Del fire omhandler normalreaksjoner etter vold, oppfølging av involverte og administrative oppgaver etter voldsepisoder, for eksempel registrering av personskader, politianmeldelse og mediehåndtering.

På en balansert og fin måte søker forfatterne å ivareta perspektivet både til helsepersonell og pasienter. Referanser til lovgrunnlag er nyttig når man skal diskutere temaet på arbeidsplassen. Om man kan lære fysiske teknikker gjennom tekst og bilder, er vel heller tvilsomt. Å mestre teknikker som skal brukes i akutte situasjoner, krever trolig mye trening, men kapitlet kan sikkert brukes som repetisjon. Uten at det er sagt tydelig gir boken et inntrykk av at forfatterne først og fremst har institusjoner med kjente brukere eller pasienter i tankene. Jeg savner noe mer spesifikt om utfordringer og tiltak der pasientene er ukjente og ikke følges over tid, som ved legevakt og akuttmottak, og der de organisatoriske rammene er helt forskjellige fra for eksempel en langtidsavdeling eller et bofellesskap. Noen skjemmende trykkfeil trekker ned helhetsinntrykket og kunne lett vært unngått med ekstra korrekturlesing.

Forfatterne går ikke i dybden. Dette er dermed ikke en bok for den som vil vite mer om forskning på temaet. De deler imidlertid sine erfaringer på en klok og lettfattelig måte. Både oppgavene til de ulike temaene og de vedlagte sjekklistene for leder, verneombud og voldsutsatt ansatt gjør det relativt enkelt å komme videre fra prat til handling. Alt $i$ alt er dette derfor en praktisk liten bok som kan være nyttig som introduksjon til temaet vold mot helsepersonell, og hvordan vold kan forebygges, håndteres og følges opp på arbeidsplassen.

Tone Morken

Forsker, Nasjonalt kompetansesenter for legevaktmedisin Uni Research Helse 